\title{
Negotiation and the clustering of corporate loan spreads
}

Citation for published version (APA):

Kleimeier, S., \& Chaudhry, S. M. (2013). Negotiation and the clustering of corporate loan spreads. Maastricht University, Graduate School of Business and Economics. GSBE Research Memoranda No. 012 https://doi.org/10.26481/umagsb.2013012

Document status and date:

Published: 01/01/2013

DOI:

10.26481/umagsb.2013012

Document Version:

Publisher's PDF, also known as Version of record

\section{Please check the document version of this publication:}

- A submitted manuscript is the version of the article upon submission and before peer-review. There can be important differences between the submitted version and the official published version of record.

People interested in the research are advised to contact the author for the final version of the publication, or visit the DOI to the publisher's website.

- The final author version and the galley proof are versions of the publication after peer review.

- The final published version features the final layout of the paper including the volume, issue and page numbers.

Link to publication

\footnotetext{
General rights rights.

- You may freely distribute the URL identifying the publication in the public portal. please follow below link for the End User Agreement:

www.umlib.nl/taverne-license

Take down policy

If you believe that this document breaches copyright please contact us at:

repository@maastrichtuniversity.nl

providing details and we will investigate your claim.
}

Copyright and moral rights for the publications made accessible in the public portal are retained by the authors and/or other copyright owners and it is a condition of accessing publications that users recognise and abide by the legal requirements associated with these

- Users may download and print one copy of any publication from the public portal for the purpose of private study or research.

- You may not further distribute the material or use it for any profit-making activity or commercial gain

If the publication is distributed under the terms of Article $25 \mathrm{fa}$ of the Dutch Copyright Act, indicated by the "Taverne" license above, 


\section{Maastricht University}

Stefanie Kleimeier, Sajid Chaudhry

Negotiation and the clustering of corporate loan spreads

RM/13/012

\section{GSBE}

Maastricht University School of Business and Economics

Graduate School of Business and Economics

P.O Box 616

NL- 6200 MD Maastricht

The Netherlands 


\title{
Negotiation and the clustering of corporate loan spreads
}

\author{
Stefanie Kleimeier ${ }^{\mathrm{a},{ }^{*}}$ and Sajid Chaudhry ${ }^{\mathrm{b}}$ \\ ${ }^{a}$ School of Business and Economics, Maastricht University, Tongersestraat 53, 6211 LM Maastricht, \\ The Netherlands \\ ${ }^{\mathrm{b}}$ Birmingham Business School, The University of Birmingham, Birmingham B15 2TT, United \\ Kingdom
}

\begin{abstract}
Most corporate loans are priced at rounded spreads, e.g. spreads that are a multiple of 25 basis points. Using a sample of 16,598 loan tranches signed by US borrowers between January 1988 and December 2010, this study explores the determinants of such interest rate clustering in the corporate syndicated loan market. We postulate that lead arrangers round spreads upwards because of the uncertainty about the riskiness of the borrowers. Consistent with this negotiation hypothesis, we find that clustering increases with the degree of uncertainty, e.g. the degree of information asymmetry between the lead arranger and the borrower. In contrast, clustering is less likely when lead arrangers have acquired information about the borrower through prior interactions. Finally, the fear of reputation loss incentivizes the most reputable lead arrangers to price loans at more competitive non-rounded spreads.
\end{abstract}

Keywords: corporate loans, interest rate clustering, negotiation hypothesis, information asymmetry, uncertainty.

JEL codes: D49, D82, G12, G21.

* Corresponding author: s.kleimeier@maastrichtuniversity.nl 


\section{Introduction}

This study analyses interest rate clustering as well as its determinants in the corporate loan market. Interest rate clustering refers to the tendency of spreads to occur most frequently at a small set of spreads, thus leading to a non-uniform distribution of spreads. The efficient market hypothesis asserts that prices rationally reflect public information about fundamental values. In an efficient capital market, the prices of loans should reflect the fundamental values of the borrower and the loan, i.e. default risk and loss given default. Across a small range of spreads, for example from 24 to $26 \mathrm{bp}$, the distribution should thus be relatively uniform and not clustered at specific spread levels. ${ }^{1}$ On the contrary, Figure 1 shows clear evidence for the clustering of interest rate spreads in the US loan market. In particular, the distribution clusters around spreads that are multiples of 25 basis points (bp) above LIBOR. This clustering tendency increases at higher spread levels. While in Figure 1 nonrounded spreads can be observed at low and moderate spread level, there are hardly any loans with non-rounded spreads above $300 \mathrm{bp}$. In the right tail of the distribution, $98 \%$ of loans with spreads of 300 bp or more are rounded.

\section{[Insert Figure 1 about here]}

Why do corporate loan spreads cluster at multiples of $25 \mathrm{bp}$ ? Why does clustering increase at higher levels of spreads? To answer these questions, we adapt the negotiation hypothesis to the corporate loan market. The negotiation hypothesis was originally presented by Ball et al. (1985) and Harris (1991) in the context of gold and stock price clustering, respectively. It postulates that clustering increases with the price level and the degree of uncertainty about the value of an asset. If the value of an asset is uncertain, traders must negotiate the exact price. Traders offer a limited set of prices in order to restrict the range of different bids and offers that can be made. Negotiations thus converge more quickly as counteroffers are restricted. The higher the uncertainty about the value, the wider the potential ranges of bids and offers and thus the higher the benefits of price restrictions. In the corporate syndicated loan market, uncertainty arises due to information asymmetry between lead arranger and borrower. During the loan syndication phase, borrowers have an information advantage regarding the quality of their investment and the effort they are willing to make after the investment has been financed. Rather than attempting to completely eliminate all information asymmetries and to price the loan at its exact risk premium, arrangers can speed up the syndication process by limiting the pricing negotiation to a set of acceptable spreads. Therefore, spreads are more likely to be rounded for loans with more substantial information asymmetries.

\footnotetext{
${ }^{1}$ This argument was first made by Osborne (1962) and Niederhoffer (1966) when describing clustering in stock prices.
} 
Our findings can be summarized as follows. First, most corporate loans in the syndicated loan market are priced at rounded spreads that are a multiple of $25 \mathrm{bp}$ and these spreads are rounded upward. Second, clustering increases with the degree of uncertainty between the lead arranger and the borrower. Third, a previous relationship between lead arranger and borrower reduces uncertainty and hence persuades lead arrangers to provide loans at exact spreads. Finally, the most reputable lead arrangers offer loans at competitive non-rounded spreads because of fear of loss of reputation.

The remainder of the paper is organized as follows. Section 2 reviews the evidence and explanations of price clustering in different financial markets while section 3 presents factual evidence regarding the price clustering in the US corporate loan market in particular. Section 4 explores to what extent the negotiation hypothesis explains the observed clustering of spreads. Section 5 provides robustness checks and section 6 concludes.

\section{Price Clustering in Financial Markets}

In many financial markets prices tend to cluster around rounded integers. For example, clustering exists in the stock market (Niederhoffer, 1966; Harris, 1991; Christie and Schultz, 1994; Ikenberry and Weston, 2007), in the foreign exchange market (Goodhart and Curcio, 1990; Sopranzetti and Datar, 2002), in the real estate market (Colwell et al., 1990), in the gold market (Ball et al., 1985), in the loan deposit market (Kahn et al., 1999; Ashton and Hudson, 2007) and in the IPO market (Ibbotson and Jaffe, 1975; Ibbotson et al., 1994; Kandel et al., 2001).

Next to negotiation benefits, the observed clustering is typically explained by tacit collusion or behavioral arguments. According to the tacit collusion hypothesis, financiers do not compete by offering lower prices but collude instead and are thus able to maintain higher, rounded prices in a given financial market. Christie and Schultz (1994) and Christie et al. (1994) find evidence for tacit collusion of NASDAQ dealers who set rounded prices in order to maintain wider non-competitive bidask spreads and hence maximize profits. Similarly, in the IPO market, Chen and Ritter (2000) use tacit collusion (which they term as strategic pricing) among investment bankers as an explanation of the high average spread, and the high frequency of seven percent spreads in this market. Tacit collusion might well apply to the corporate loan market which is highly concentrated, e.g. where only a few lead arrangers capture substantial market share. However, our findings will indicate that lead arrangers with the highest market share are actually less likely to offer rounded spreads. We thus favor the negotiation hypothesis over the tacit collusion hypothesis.

For the retail banking market, Kahn et al. (1999) and Ashton and Hudson (2008) provide a behavioral explanation for clustering. Kahn et al. (1999) develop a limited recall model and show, both theoretically and empirically, that retail deposit rates cluster around integers and even fractions. They argue that individuals tend to memorize truncated prices rather than full prices and clustering arises due to limited number recall. In their model, two extreme types of depositors exist sophisticated depositors with full-recall and naïve depositors who remember only the integer of the 
deposit rate. Banks maximize revenue from naïve depositors who truncate numbers. As naïve depositors truncate interest rates to the nearest full integer, they perceive rates of $6.1 \%$ or $6.7 \%$ or $6.99 \%$ as equal to $6 \%$ and the bank can thus maximize profits by setting the interest rate to $6 \%$. With many more naïve than full-recall depositors in the market, interest rates will cluster at integers. Ashton and Hudson (2008) add rounding to truncation in the customers' limited recall model and confirm that in the UK retail deposit and mortgage markets interest rate clustering occurs in a manner consistent with bank's profit maximization. While deposit rates cluster at integers, mortgage rates cluster just below integers. Using the same example as above, naïve borrowers would truncate mortgage rates of $6.1 \%$ or $6.7 \%$ or $6.99 \%$ to $6 \%$ and the bank maximizes profits by setting the mortgage rate to $6.99 \%$. While limited recall can explain clustering in the retail mortgage market, it fails to apply in the corporate loan market where spreads are clustered at whole, half or quarters of a percent rather than just below it. We therefore explore an explanation based on negotiation cost instead.

\section{Spread Clustering in the US Corporate Loan Market}

The negotiation hypothesis postulates that negotiations about the price of an asset whose value is uncertain converge more quickly when counteroffers are restricted to a limited set of prices. The higher the uncertainty about the asset's value, the wider the potential ranges of price offers and counteroffers and the higher the benefits of price restrictions. In order to test whether the negotiation hypothesis can explain the observed clustering of corporate loan spreads, we examine 16,598 loan tranches raised by US borrowers between January 1988 and December 2010 that are priced at a spread relative to LIBOR. We obtain these data from the Loan Pricing Corporation's (LPC) Dealscan database. Our sample includes all loans for which the borrower name and industry, loan purpose, tranche amount, date of loan signing, loan maturity, identity and lending shares of the syndicate members, base rate and margin and the borrower's sales volume at loan signing are available in the database.

We focus on the tranche rather than deal level, as interest rates are tranche specific. We extract the spread over LIBOR from the "Base Rate Margin" field in Dealscan. In case of multiple base rates for a single tranche, we only consider the LIBOR-based spread and disregard the spreads over other base rates. A spread is considered to be rounded if it is a multiple of $25 \mathrm{bp}$. In addition to Figure 1 above, Table I shows the distribution of spreads in more detail. Rounded spreads occur for $64 \%$ of all observations. Among the 16,598 loans, 28 spread levels occur more than 100 times and 16 of these spreads are rounded, e.g. the spreads are multiples of $25 \mathrm{bps}$. Among these 28 spreads, the 11 most frequently occurring spreads are all rounded and account for $57 \%$ of our sample. In total, our 16,598 tranches are priced at 302 different spread levels of which 40 (13.2\%) are rounded. However, these $13.2 \%$ of spread levels disproportionally account for $65.5 \%$ of all tranches. Thus, spreads are clearly 
clustered at rounded levels and rounded spreads are the rule rather than the exception in the US corporate loan market.

\section{[Insert Table I about here]}

Evidence provided by Kahn et al. (1999) and Ashton and Hudson (2008) for the UK retail banking market indicates that banks maximize profits, e.g. round or truncate interest rates in the bank's favor. Therefore we first want to establish whether or not banks in the corporate loan market also round spreads in their favor. To do so, we estimate loan-pricing regressions in which the actual spread in bp over LIBOR serves as the dependent variable. In line with the empirical loan pricing literature (see for example Booth, 1992; Gorton and Pennacchi, 1995; Carey and Nini, 2007; Ivashina, 2009; Gatti et al., 2012), we model the spread as a function of borrower and loan characteristics and consider the following potential determinants of loan spreads: The borrower's risk based on its rating, borrower size based on sales in millions of US dollar, tranche size in millions of US dollar, tranche maturity in years, and dummies identifying secured tranches, senior tranches, tranches with covenants, term loans and tranches belonging to multiple-tranche deals. We also include year, industry and loan purpose dummies. $^{2}$

Table II provides a loan pricing regression based on our sample of 16,598 tranches. To investigate whether spreads are on average rounded upwards or downwards, we include a dummy equal to 1 if the spread is rounded, e.g. is a multiple of $25 \mathrm{bp}$, and 0 otherwise. In regression 1 we include only borrower characteristics. In regression 2 , we add the potentially endogenous loan characteristics. However, as a comparison between regressions 1 and 2 shows, the inclusion of the loan characteristics does not change the sign and significance of the borrower characteristics' coefficients. In general, the coefficients of our explanatory variables are in line with the existing loan pricing evidence. Our interest focusses on the coefficient for the rounded spread dummy. We find positive coefficients indicating that loans with rounded spreads are on average $74.60 \mathrm{bp}$ (regression 1) or $53.05 \mathrm{bp}$ (regression 2) more expensive than loans with non-rounded spreads. To further this evidence, we estimate loan-pricing regressions on the sub-sample of 5,721 loans that are priced at exact, e.g. non-rounded spreads over LIBOR. Results are shown in Panel A of Table III. Based on these regressions, we predict what the exact spread should have been for those 10,877 tranches that are actually priced a rounded spreads. In Panel B of Table III, we find that the average actual spread is much higher than the predicted spread i.e., 74.9 and $57.3 \mathrm{bp}$ for regression 1 and regression 2 respectively, a result which is in line with the coefficients of the rounded spread dummy in Table II. About $3 / 4$ of loan tranches have actual rounded spreads higher than their predicted spread. We conclude

\footnotetext{
${ }^{2}$ The exact definition of all the variables is given in Table A-I in the Appendix.
} 
from this finding that lead arrangers in the corporate loan market act in their own interest similar to banks in the retail mortgage market.

[Insert Tables II and III about here]

\section{Explaining Spread Clustering with the Negotiation Hypothesis}

According to the negotiation hypothesis, the bank's uncertainty about the true value and risk of the loan is the core determinant of spread clustering. When faced with moderate uncertainty, banks can reduce information asymmetries by screening the borrower and thus price the loan at an appropriate and relatively exact risk premium. However, when the banks face substantial information asymmetries, screening might be too costly and banks can instead opt to enter into a price negotiation process with the borrower in which possible spreads are limited and the loan is ultimately priced at an approximate, upward-rounded spread. Consequently, the negotiation hypothesis predicts that spreads are more likely to be rounded for loans with more substantial information asymmetries. To test this prediction, we estimate a logit model in which the dependent variable is defined as 1 if the loan is priced at a rounded spread and 0 otherwise.

We consider several proxies for the information asymmetry between the bank and the borrower that reflect the bank's uncertainty about the true price of the loan. Our first two proxies are direct measures for the amount of information asymmetry between lender and borrower. We consider whether or not a borrower has a rating and whether or not it has a ticker indicating that it has traded securities outstanding. The existence of a rating or ticker indicates that information about the borrower is more easily available either directly from a rating agency or indirectly through the public information requirements that go hand in hand with a security listing (Dennis and Mullineaux, 2000; Lee and Mullineaux, 2004; Sufi, 2007; Chaudhry and Kleimeier, 2012). We classify a borrower as an unrated borrower if no S\&P senior debt rating is available and as a borrower without ticker if no ticker is available in the Dealscan database. Both proxies are coded as dummies which take the value of 1 if information asymmetry is higher and 0 otherwise.

In addition we employ two proxies that measure whether the borrower is known to the corporate loan market. First, we postulate that if the borrower has accessed the loan market in the past, he is already known among banks and information asymmetry may therefore be reduced (Sufi, 2007; Chaudhry and Kleimeier, 2012). In line with Chaudhry and Kleimeier (2012) who find stronger effects of information asymmetry reduction for more recent the borrowers, we define previous borrower as the number of loans a borrower raised during the previous three years. Second, we consider whether or not the lead arranger of the current loan is a former lead arranger, e.g. has a prior lending relationship with the borrower and thus faces less information asymmetry. Sufi (2007) was the first one to consider this proxy as a measure of information asymmetry while earlier studies by Dennis and Mullineaux 
(2000) and Lee and Mullineaux (2004) interpreted this proxy as a measure of the lead arranger's reputation. We follow Sufi's information asymmetry interpretation and define our proxy of former lead arranger as a dummy equal to 1 if the current lead arranger has also served as a lead arranger for the borrower during the prior three years and 0 otherwise.

Next we consider the riskiness of the borrower. Figure 1 shows that at high levels of spreads, e.g. for risky borrowers, there are very few non-rounded spreads. For example among the 1,198 tranches with spreads above $300 \mathrm{bp}$, only 45 tranches (3.8\%) are priced at non-rounded spreads. These observations are in line with the negotiation hypothesis as the potential range of price offers and counteroffers is wider at higher price levels and thus the benefits of price restrictions are more substantial. Our model therefore includes a proxy for the loan tranche's actual spread level in basis points above LIBOR.

According to Ashton and Hudson (2008), the degree of price or interest rate clustering appears to be prominent when low levels of financial involvement are concerned. We postulate that the financial stake increases with the size of the loan - either in absolute terms or relative to borrower size - and borrowers are more inclined to negotiate for exact spreads when loans are large. Our first proxy of relative loan size is calculated as the tranche amount divided by borrower sales. Secondly, we create a large loan dummy, which is equal to 1 if the loan in terms of relative loan size belongs to the top 33 percentile and 0 otherwise.

As our loan pricing analysis has shown, spreads are rounded upwards leading to higher cost for the borrower. However, fear of reputational loss might prevent lead arrangers from engaging in such profit maximizing behavior. We therefore postulate that more reputable lead arrangers are less likely to offer rounded spreads. We measure reputation as the lead arranger market share in the year prior to loan signing. However, as the corporate syndicated loan market is highly concentrated, and only a few lead arrangers capture substantial market shares, we also consider a top lead arranger dummy which is coded as 1 if the lead arranger is among the three lead arrangers with the highest market share in the corporate loan market in the year prior to loan signing and 0 otherwise.

Finally, we control for unobserved industry, year and loan purpose effect by including the respective dummies.

Table IV provides descriptive statistics for all tranches, for tranches with rounded spreads and for tranches with non-rounded spreads, respectively. Our sample contains 10,877 loan tranches with rounded spreads and 5,721 loan tranches with non-rounded spreads. Regarding our primary dependent variable the mean spread above LIBOR in basis points is 157.85 bp with a standard deviation of $113.48 \mathrm{bp}$ for all the tranches. However, the mean spread of tranches with rounded spreads is 200.52 bp and as such substantially higher than mean spread of non-rounded spread of $76.74 \mathrm{bp}$. This observation leads us provide robustness checks where we exclude loans with extreme spreads from the sample. Each loan tranche has on average two base rates. For example, a loan could be priced at both LIBOR plus $50 \mathrm{bp}$ and PRIME plus $75 \mathrm{bp}$ and the borrowers can choose at each payment date which 
interest rate to pay. Here loans with rounded LIBOR spreads clearly differ from loans with nonrounded LIBOR spreads: For the former group of loans, the average fraction of base rates with rounded spreads is 0.97 indicating that if the LIBOR spread is rounded, almost all the other spreads are rounded too. For the latter group of loans, however, this fraction is only 0.39 . While our main analysis focuses on the rounded versus non-rounded spread above LIBOR, we investigate the number of rounded spreads per tranche in a robustness check.

Regarding the potential determinants of rounded spreads, rounded spreads more frequent when the information asymmetry between borrower and lender is high. In particular, $68 \%$ of all tranches with rounded spreads are raised by unrated borrowers compared to only $41.7 \%$ of tranches with nonrounded spreads. Similar differences can be found for borrowers without ticker (36.6\% versus $24.2 \%$ ). Previous borrowers are more likely to borrow at non-rounded spreads and former lead arrangers are more likely to lend at non-rounded spreads (44.2\% versus $34.2 \%$ ). Overall, these univariate results provide the first evidence in support of the negotiation hypothesis. In addition, more important loans are less frequently rounded but standard deviations as tranches with non-rounded spreads are larger by on average $50 \%$ in terms of relative loan size. Finally, we observe that more reputable lead arrangers are less likely to offer loans at rounded spreads. However, this pattern is most distinct only for the most reputable lead arrangers.

[Insert Table IV about here]

Panel A of Table V reports our baseline results regarding the negotiation hypothesis. Here we include our explanatory variables in different combinations: Regressions 1 and 2 use our lead arranger market share proxy while regressions 3 and 4 use the top lead arranger proxy. In regressions 1 and 3 we employ only the relative loan size proxy while we add the large loan dummy in regressions 2 and 4. As our dependent variable is a dummy, we estimate logit regressions and report marginal effects. Our results indicate that rounded spreads are more likely when information asymmetry is stronger. In line with the negotiation cost hypothesis, the marginal effects for an unrated borrower and a borrower without ticker are significantly positive while the marginal effect of former lead arranger is significantly negative. In contrast, being a previous borrower appears to reduce information asymmetry and thus clustering only marginally. As expected clustering is more frequent when spreads are high indicating that uncertainty about the riskiness of the borrower matters, e.g. that the benefits of price restrictions are more substantial at higher spread levels. Furthermore, financial involvement matters only for the largest loans - here the negative marginal effect indicates that borrowers are indeed inclined to negotiate for exact spreads when loans are very large. Finally, the insignificant marginal effect of lead arranger market share compare to the significantly negative marginal effect of top lead arranger indicates that reputational concerns only appear to affect the most reputable banks. We therefore conclude that only the most reputable lead arrangers do not exploit the 
borrower by rounding the interest rate spreads upwards as they are concerned about their loss of reputation.

Based on regression 4 of Panel A, Panel B of Table V considers the economic impact of our clustering determinants in more detail. We reports the changes in predicted probabilities of loan being priced at a rounded spread above LIBOR based on a one-standard deviation change in an independent continuous variable or a change from 0 to 1 for an independent dummy variable. The lack of a rating has the highest impact: Unrated borrowers are $46.7 \%$ more likely to borrow at a rounded spread than rated borrowers. Secondly, borrowers with higher spread levels are $32.0 \%$ more likely to borrow at rounded spreads as compared to the borrowers with lower spread levels. Thirdly, large loans are $14.3 \%$ less likely to be priced at rounded spreads. For our other proxies, the impact is substantially lower.

[Insert Table V about here]

So far we assumed that all spreads that are a multiple of $25 \mathrm{bp}$ are rounded. Now, we consider different levels of rounding with the expectation that more severe the uncertainty leads to a more restricted negotiation options and thus to more extreme rounding. To differentiate these different levels of rounding we estimate an ordered logit model in Table VI. In model 1, we focus on three categories of spreads: no rounding, rounding at multiples of $25 \mathrm{bp}$ but not $50 \mathrm{bp}$, rounding at multiples of $50 \mathrm{bp}$. In model 2, we focus on four categories of spreads: no rounding, rounding at multiples of 25 bp but not $50 \mathrm{bp}$ or $100 \mathrm{bp}$, rounding at multiples of $50 \mathrm{bp}$ but not $100 \mathrm{bp}$, rounding at multiples of 100 bp.

Model 1 shows that the impact of borrower without ticker and former lead arranger are only significant for spreads rounded at multiples of $50 \mathrm{bp}$ while the impact of unrated borrower, spread level, large loan and top lead arranger is substantially stronger for rounding at the level of $50 \mathrm{bp}$. Model 2 however reveals that the effects do not change any further when rounding at multiples of 100 bp are considered in addition. With the exception of unrated borrower, the marginal effects are identical for the $50 \mathrm{bp}$ and $100 \mathrm{bp}$ rounding levels. Overall, we therefore conclude that uncertainty about the true price of the loan leads to rounding at multiples of at least $25 \mathrm{bp}$ and that higher levels of uncertainty leads to more severe rounding with the main impact confined to multiples of $50 \mathrm{bp}$.

[Insert Table VI about here]

\section{Robustness Checks}

As we noticed in Figure I that there are numerous observations with large spreads and these are more frequently rounded. In our benchmark analysis in Table III, we already control for this feature of the corporate loan market by including the loan's actual spread. In order to additionally 
check the robustness of our results, we exclude observations with extreme spreads and re-estimate regression 4 of Table $\mathrm{V}$ with these reduced samples. We exclude tranches that fall into the top 1\%, top $5 \%$, top and bottom $1 \%$ and top and bottom $1 \%$ of the spread distribution, respectively. Table VII presents our findings and shows that our results are robust and not driven by tranches with extreme spreads.

[Insert Table VII about here]

Next we consider an alternative proxy for our dependent variable. As a single tranche can be priced relative to multiple base rates, we consider the fraction of base rates with rounded spreads relative to the total number of base rates. In Table VII we replicate regression 4 of Table V but use our alternative dependent variable and estimate a tobit regression. Our results are robust as we find that all of our variables carry the same signs and significance except lead arranger reputation. We therefore conclude that there is indeed uncertainty driven by information asymmetry between the borrower and the lead arranger, leading to rounded interest rate spreads in the corporate loan market.

\section{[Insert Table VIII about here]}

\section{Summary and Conclusion}

Based on the observation that spreads in the US corporate loan market cluster at certain levels, we set out to answer two questions: Why do corporate loan spreads cluster? Why does clustering increase at higher levels of spreads? Our results support the negotiation hypothesis which postulates that negotiations about the price of an asset whose value is uncertain converge more quickly when counteroffers are restricted to a limited set of prices. The higher the uncertainty about the asset's value, the wider the potential ranges of price offers and counteroffers and the higher the benefits of price restrictions. In the corporate loan market, clustering increases with the degree of uncertainty, e.g. information asymmetry between the lead arranger and the borrower. However, a previous lending relationship between lead arranger and borrower reduces this uncertainty and hence persuades lead arrangers to provide loans at exact spreads. As loans are generally priced at upwardly rounded spreads, we can observe that the most reputable lead arrangers offer loans at competitive non-rounded spreads because of fear of loss of reputation.

Our findings have clear implications for market participants i.e. corporate managers. Information asymmetries between corporations and their financiers are known to negatively affect access to finance (Diamond, 1984; Battahcharya and Thakor, 1993). Petersen and Rajan (1994) for example show that small businesses benefit from closer ties with banks and can raise funds more easily. Cole (1998) also shows that firms with pre-existing relationships with a bank are less credit constrained. Our study identifies an additional adverse effect of information asymmetry: In addition to 
limited access to credit, informationally opaque borrowers who nevertheless manage to raise loan financing are only able to do so at a higher cost. Reducing information asymmetries will thus be doubly beneficial to these borrowers. This is especially important after the 2007/08 financial crisis. Loans markets are only slowly recovering from severe credit rationing and access to loan finance is difficult not only but especially so for informationally opaque companies. As the economic effects of the crisis are still strongly felt in terms of low economic growth and reduced corporate profit margins, access to low-cost funding is critical.

\section{Appendix}

[Insert Table A-I here] 


\section{References}

Ashton, J. K., \& Hudson, R. S. (2008). Interest rate clustering in UK financial services markets. Journal of Banking \& Finance, 25, 1393-1403.

Ball, C. A., Torouse, W., \& Tschoegl, A. (1985). The degree of price resolution: The case of gold market. Journal of Futures Markets, 5, 29-43.

Berger, A., \& Udell, G. F. (1995). Relationship lending and lines of credit in small finance firms. Journal of Business, 68, 351-381.

Bhattacharaya, S., \& Thakor, A. V. (1993). Contemporary banking theory, Journal of Financial Intermediation, 3, 2-50.

Carey, M., \& Nini, G. (2007). Is the corporate loan market globally integrated? A pricing puzzle. Journal of Finance, 62(6), 2969-3008.

Chaudhry, S., \& Kleimeier, S. (2012). Information asymmetry and the structure of loan syndicates. Working paper.

Chen, H., \& Ritter, R. J. (2000). The seven percent solution. Journal of Finance, 55(3), 1105-1131.

Christie, W. G., \& Schultz, P. H. (1994). Why do NASDAQ market makers avoid odd-eighth quotes? The Journal of Finance, 41(3), 1813-1840.

Christie, W. G., Harris, H. J., \& Schultz, P. H. (1994). Why did NASDAQ market makers stop avoiding odd-eighth quotes? Journal of Finance, 49(5), 1841-1860.

Cole, R. A. (1998). The importance of relationships to the availability of credit. Journal of Banking and Finance, 22(6-8), 959-977.

Colwell, P., Rushing, P., \& Young, K. (1994). The rounding of appraisal estimates. Illinois Real Estate Letter.

Dennis, S. A., \& Mullineaux, D. J. (2000), Syndicated loans, Journal of Financial Intermediation, 9, 404-426.

Diamond, D. W. (1984). Financial intermediation and delegated monitoring. Review of Economic Studies, 51(3), 393-414.

Gatti, S., Kleimeier, S., Megginson, W.L., \& Steffanoni, A. (2013). Arranger certification in project finance. Financial Management, Spring, 1-40.

Goodhart, C., \& Curcio, R. (1990). Asset price discovery and price clustering in the foreign exchange market. Working paper, London School of Economics.

Gorton, G., \& Pennacchi, G. (1995). Banks and loan sales: marketing non-marketable assets. Journal of Monetary Economics, 35, 389-411.

Ibbotson, R. G., Sindelar, J. L., \& Ritter, J. R. (1994). The market's problem with the pricing of initial public offerings. Journal of Applied Corporate Finance, 7, 66-74. 
Ikenberry, D. L., \& Weston, J. P. (2007). Clustering in US stock prices after decimalization. European Financial Management, 14(1), 30-54.

Ivashina, V. (2009). Asymmetric information effects on loan spreads. Journal of Financial Economics, 92(2), 300-319.

Kahn, C., Pennacchi, G., \& Sopranzetti, B. (1999). Bank deposit rate clustering: Theory and empirical evidence. Journal of Finance, 54, 2185-2214.

Kandel, S., Sarig, O., \& Whol, A. (2001). Do investors prefer round stock prices? Evidence from Israeli IPO auctions. Journal of Banking \& Finance, 25, 1543-1551.

Lee, S. W., \& Mullineaux, D. J. (2004), Monitoring, financial distress and the structure of commercial lending syndicates, Financial Management, Autumn, 107-130.

Niederhoffer, V. (1966). A new look at clustering of stock prices. Journal of Business, 39, 390-413.

Niederhoffer, V., \& Osborne, M. (1966). Market making and reversal on the stock exchange. Journal of the American Statistical Association, 61, 897-916.

Petersen, M. A., \& Rajan, R. (1994). The benefits of lending relationships: Evidence from small business data. Journal of Finance, 49(1), 3-37.

Sopranzetti, B. J., \& Datar, V. (2002). Price clustering in foreign exchange spot markets. Journal of Financial Markets, 5(4), 411-417.

Sufi, A. (2007). Information asymmetry and financing arrangements: evidence from syndicated loans. Journal of Finance, 62(2), 629-668. 
Figure I

The distribution of spreads

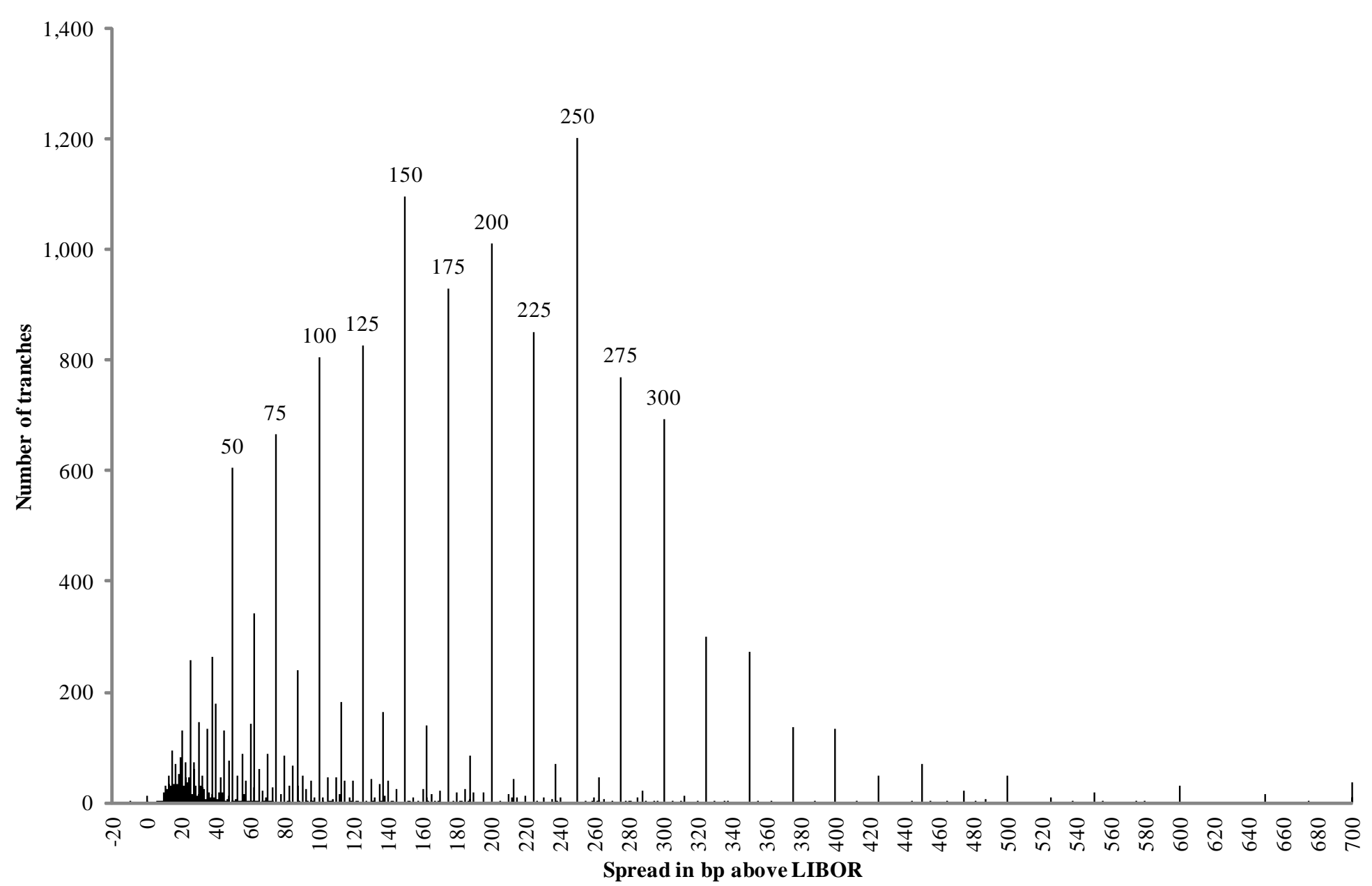

Notes: This figure shows the number of loan tranches for a given spread in basis points (bp) above LIBOR. The total sample consists of 16,598 tranches raised by US borrowers from 1988 to 2010 . For frequencies above 500 tranches, the numbers above the bars indicate the spread in bp. The sample contains 37 tranches with spreads above $700 \mathrm{bp}$ which are not shown in the histogram. 
Table I

The distribution of spreads

This table shows the distribution of loans across different spread levels. A spread is considered to be rounded if it is a multiple of 25 basis points above LIBOR. Only spreads which are applied to 100 loans or more are shown.

\begin{tabular}{|c|c|c|c|c|}
\hline Spread & $\mathrm{in} b p$ & $\begin{array}{r}\text { Number of } \\
\text { tranches }\end{array}$ & $\%$ of sample & $\begin{array}{r}\text { Cumulative \% } \\
\text { of sample }\end{array}$ \\
\hline & 250 & 1,202 & $7.2 \%$ & $7.2 \%$ \\
\hline & 150 & 1,096 & $6.6 \%$ & $13.8 \%$ \\
\hline & 200 & 1,011 & $6.1 \%$ & $19.9 \%$ \\
\hline & 175 & 930 & $5.6 \%$ & $25.5 \%$ \\
\hline & 225 & 852 & $5.1 \%$ & $30.7 \%$ \\
\hline & 125 & 827 & $5.0 \%$ & $35.7 \%$ \\
\hline & 100 & 805 & $4.8 \%$ & $40.5 \%$ \\
\hline & 275 & 770 & $4.6 \%$ & $45.1 \%$ \\
\hline & 300 & 693 & $4.2 \%$ & $49.3 \%$ \\
\hline & 75 & 665 & $4.0 \%$ & $53.3 \%$ \\
\hline & 50 & 605 & $3.6 \%$ & $57.0 \%$ \\
\hline & 62.5 & 342 & $2.1 \%$ & $59.0 \%$ \\
\hline & 325 & 299 & $1.8 \%$ & $60.8 \%$ \\
\hline & 350 & 273 & $1.6 \%$ & $62.5 \%$ \\
\hline & 37.5 & 263 & $1.6 \%$ & $64.1 \%$ \\
\hline & 25 & 257 & $1.5 \%$ & $65.6 \%$ \\
\hline & 87.5 & 239 & $1.4 \%$ & $67.1 \%$ \\
\hline & 112.5 & 181 & $1.1 \%$ & $68.1 \%$ \\
\hline & 40 & 179 & $1.1 \%$ & $69.2 \%$ \\
\hline & 137.5 & 163 & $1.0 \%$ & $70.2 \%$ \\
\hline & 30 & 147 & $0.9 \%$ & $71.1 \%$ \\
\hline & 60 & 144 & $0.9 \%$ & $72.0 \%$ \\
\hline & 162.5 & 141 & $0.8 \%$ & $72.8 \%$ \\
\hline & 375 & 137 & $0.8 \%$ & $73.6 \%$ \\
\hline & 35 & 134 & $0.8 \%$ & $74.4 \%$ \\
\hline & 400 & 133 & $0.8 \%$ & $75.2 \%$ \\
\hline & 20 & 131 & $0.8 \%$ & $76.0 \%$ \\
\hline & 45 & 130 & $0.8 \%$ & $76.8 \%$ \\
\hline \multicolumn{5}{|l|}{ All other spread levels } \\
\hline Of which 24 are rounded spread levels & & 395 & $2.4 \%$ & \\
\hline Of which 250 are non-rounded spread levels & & 3,457 & $20.8 \%$ & \\
\hline Total & & 16,598 & $100.0 \%$ & \\
\hline
\end{tabular}


Table II

\section{Loan pricing analysis}

This table shows results of an OLS regression based on a sample of loans which are priced at both rounded as well as non-rounded spreads. The rounded spread dummy indicates a spread that is a mulitple of $25 \mathrm{bp}$. For each independent variable, the coefficient is reported in the top row and the t-statistic is reported in the bottom row. $* * *, * *$ and $*$ indicate significance at the $1 \%, 5 \%$ and $10 \%$ level respectively. Standard errors are heteroscedasticity robust and clustered at the borrower level. Subscript D indicates a dummy variable.

\begin{tabular}{|c|c|c|}
\hline \multirow[t]{2}{*}{ Dependent variable } & \multicolumn{2}{|c|}{ Spread above LIBOR } \\
\hline & (1) & (2) \\
\hline \multirow[t]{2}{*}{ Intercept } & $348.89 * * *$ & $337.96 * * *$ \\
\hline & 15.31 & 13.90 \\
\hline \multirow[t]{2}{*}{ Rounded spread $_{\mathrm{D}}$} & $74.60 * * *$ & $53.05 * * *$ \\
\hline & 38.66 & 29.91 \\
\hline \multirow[t]{2}{*}{ S\&P senior debt rating class $B_{D}$} & $38.41 * * *$ & $25.47 * * *$ \\
\hline & 13.90 & 10.24 \\
\hline \multirow[t]{2}{*}{ S\&P senior debt rating class $C_{D}$} & $46.20 * * *$ & $35.70 * * *$ \\
\hline & 20.18 & 17.37 \\
\hline \multirow[t]{2}{*}{ S\&P senior debt rating class $D_{D}$} & $119.38 * * *$ & $92.51 * * *$ \\
\hline & 9.75 & 7.47 \\
\hline \multirow[t]{2}{*}{ Unrated borrower ${ }_{D}$} & $137.75 * * *$ & $105.65 * * *$ \\
\hline & 6.71 & 5.35 \\
\hline \multirow[t]{2}{*}{ Borrower size } & $-17.26 * * *$ & $-8.22 * * *$ \\
\hline & -24.01 & -10.54 \\
\hline \multirow[t]{2}{*}{ Tranche size } & & $-10.93 * * *$ \\
\hline & & -13.47 \\
\hline \multirow[t]{2}{*}{ Loan maturity } & & $-2.30 *$ \\
\hline & & -1.72 \\
\hline \multirow[t]{2}{*}{ Secured $_{D}$} & & $54.95 * * *$ \\
\hline & & 26.71 \\
\hline \multirow[t]{2}{*}{ Senior $_{D}$} & & $-9.66 * * *$ \\
\hline & & -2.60 \\
\hline \multirow[t]{2}{*}{ Covenants $_{\mathrm{D}}$} & & 5.02 \\
\hline & & 0.64 \\
\hline \multirow[t]{2}{*}{ Term loan $_{D}$} & & $15.35 * * *$ \\
\hline & & 6.48 \\
\hline \multirow[t]{2}{*}{ Multiple tranche $_{\mathrm{D}}$} & & $18.10 * * *$ \\
\hline & & 10.41 \\
\hline Year dummies & yes & yes \\
\hline Industry dummies & yes & yes \\
\hline Loan purpose dummies & yes & yes \\
\hline Adjusted $\mathrm{R}^{2}$ & 0.476 & 0.547 \\
\hline Number of observations & 16,598 & 16,598 \\
\hline
\end{tabular}


Table III

\section{Loan pricing analysis}

Panel A shows results of an OLS regression based on a sample of loans which are priced at nonrounded spreads over LIBOR. A spread is considered to be non-rounded when it is not a mulitple of 25 bp. For each independent variable, the coefficient is reported in the top row and the t-statistic is reported in the bottom row. $* * *, * *$ and $*$ indicate significance at the $1 \%, 5 \%$ and $10 \%$ level respectively. Standard errors are heteroscedasticity robust and clustered at the borrower level. Subscript D indicates a dummy variable.

Panel A: Loan pricing regression for loans with non-rounded spreads

Intercept

$\mathrm{S} \& \mathrm{P}$ senior debt rating class $\mathrm{B}_{\mathrm{D}}$

$\mathrm{S} \& \mathrm{P}$ senior debt rating class $\mathrm{C}_{\mathrm{D}}$

S\&P senior debt rating class $\mathrm{D}_{\mathrm{D}}$

Unrated borrower $_{D}$

Borrower size

Tranche size

Loan maturity

Secured $_{D}$

Senior $_{D}$

Covenants $_{\mathrm{D}}$

Term loan $_{\mathrm{D}}$

Multiple tranche $e_{\mathrm{D}}$

Year dummies

Industry dummies

Loan purpose dummies

Adjusted $\mathrm{R}^{2}$

Number of observations
(1)

7

752.1

32.05

$32.52 * * *$

18.04

$132.67 * * *$

5.11

$162.09 * * *$

2.79

$35.61 * * *$

14.04

$-14.93 * * *$

$-18.41$

(2)

$\begin{array}{lc}-18.41 & -11.39 \\ & -7.02 * * * \\ & -7.83 \\ & -1.29 \\ & -1.06 \\ & 48.92 * * * \\ & 16.88 \\ & -10.56 * * \\ & -2.04 \\ & -5.12 \\ & -0.52 \\ & 12.88 * * * \\ & 3.91 \\ & 9.72 * * * \\ & 4.83 \\ & \text { yes } \\ \text { yes } & \text { yes } \\ \text { yes } & \text { yes } \\ \text { yes } & \\ & 0.538 \\ 0.439 & 5,721 \\ 5,721 & \end{array}$

Panel B: Comparing predicted and actual spreads for loans with rounded spreads

Average predicted spread in bp

Average actual spread in $b p$

Average actual minus predicted spread in $b p$ 
Table IV

Descriptive statistics

This table shows the characteristics of loans, borrowers and lenders for the sample of 16,598 loans with LIBOR as base rate. A spread is considered to be rounded if it is a multiple of 25 basis points above LIBOR. The sample contains 10,877 loans with rounded spreads and 5,721 loans with non-rounded spreads. Subscript D indicates a dummy variable.

\begin{tabular}{|c|c|c|c|c|c|c|c|c|c|c|c|c|c|c|c|}
\hline & \multicolumn{5}{|c|}{ All tranches } & \multicolumn{5}{|c|}{ Tranches with rounded spreads } & \multicolumn{5}{|c|}{ Tranches with non-rounded spreads } \\
\hline & $\begin{array}{r}\text { Dummy } \\
\text { equal to } 1\end{array}$ & Mean & $\begin{array}{r}\text { Standard } \\
\text { deviation }\end{array}$ & Minimum & Maximum & $\begin{array}{r}\text { Dummy } \\
\text { equal to } 1\end{array}$ & Mean & $\begin{array}{r}\text { Standard } \\
\text { deviation }\end{array}$ & Minimum & Maximum & $\begin{array}{r}\text { Dummy } \\
\text { equal to } 1\end{array}$ & Mean & $\begin{array}{r}\text { Standard } \\
\text { deviation }\end{array}$ & Minimum & Maximum \\
\hline Spread level & & 157.85 & 113.48 & -20.00 & $1,300.00$ & & 200.52 & 109.47 & 0.00 & 1300.00 & & 76.74 & 67.36 & -20.00 & 921.00 \\
\hline Number of different base rates & & 2.00 & 0.53 & 1.00 & 6.00 & & 2.00 & 0.50 & 1.00 & 4.00 & & 2.01 & 0.58 & 1.00 & 6.00 \\
\hline $\begin{array}{l}\text { Fraction of base rates with } \\
\text { rounded spreads }\end{array}$ & & 0.77 & 0.32 & 0.00 & 1.00 & & 0.97 & 0.12 & 0.00 & 1.00 & & 0.39 & 0.23 & 0.00 & 1.00 \\
\hline Unrated borrower ${ }_{\mathrm{D}}$ & $59.0 \%$ & & & & & $68.0 \%$ & & & & & $41.7 \%$ & & & & \\
\hline Borrower without ticker $_{D}$ & $32.4 \%$ & & & & & $36.6 \%$ & & & & & $24.2 \%$ & & & & \\
\hline Previous borrower & & 0.83 & 1.41 & 0.00 & 31.00 & & 0.72 & 1.38 & 0.00 & 31.00 & & 1.03 & 1.45 & 0.00 & 15.00 \\
\hline Former lead arranger ${ }_{D}$ & $37.7 \%$ & & & & & $34.2 \%$ & & & & & $44.2 \%$ & & & & \\
\hline Relative loan size & & 0.73 & 10.77 & 0.00 & $1,250.00$ & & 0.64 & 3.95 & 0.00 & 186.57 & & 0.91 & 17.52 & 0.00 & $1,250.00$ \\
\hline Large loan ${ }_{D}$ & $43.7 \%$ & & & & & $31.5 \%$ & & & & & $66.9 \%$ & & & & \\
\hline Top lead arranger ${ }_{D}$ & $24.9 \%$ & & & & & $19.7 \%$ & & & & & $34.8 \%$ & & & & \\
\hline
\end{tabular}


Table V

\section{Determinants of spread rounding}

This table shows results of logit regressions. The dependent variable is coded as 1 when the spread over LIBOR of the loan tranche is rounded at $25 \mathrm{bp}$ or a mutliple thereof and 0 otherwise. In Panel A, the marginal effect is reported in the top row and the $\mathrm{z}$-statistic is reported in the bottom row. For dummy variables, the marginal effect of a change from 0 to 1 is reported. All marginal effects are calculated at the means. ***,** and * indicate significance at the $1 \%, 5 \%$ and $10 \%$ level respectively. Standard errors are heteroscedasticity robust and clustered at the borrower level. In Panel B, the predicted probabilities of a rounded spread are reported when the respective independent variable moves from half a standard deviation below the mean to half a standard deviation above the mean. For dummy variables a shift from 0 to 1 is considered instead. All other independent variables are set to their means. Subscript $D$ indicates a dummy variable.

\begin{tabular}{|c|c|c|c|c|c|c|c|}
\hline \multicolumn{8}{|l|}{ Panel A: Marginal effects } \\
\hline \multirow[t]{2}{*}{ Dependent variable } & \multicolumn{7}{|c|}{ Rounded spread $_{D}$} \\
\hline & $(1)$ & $(2)$ & & (3) & & $(4)$ & \\
\hline \multirow[t]{2}{*}{ Unrated borrower $_{\mathrm{D}}$} & $0.544 * * *$ & 0.466 & $* * *$ & 0.535 & $* * *$ & 0.460 & $* * *$ \\
\hline & 38.390 & 28.670 & & 37.190 & & 28.160 & \\
\hline \multirow{2}{*}{ 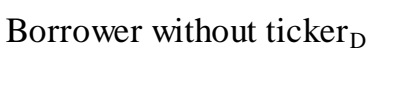 } & $0.043 * * *$ & 0.040 & $* * *$ & 0.042 & $* * *$ & 0.039 & $* * *$ \\
\hline & 3.520 & 3.290 & & 3.460 & & 3.220 & \\
\hline \multirow[t]{2}{*}{ Previous borrower } & $-0.019 *$ & -0.011 & & -0.018 & $*$ & -0.011 & \\
\hline & -1.730 & -1.020 & & -1.600 & & -0.950 & \\
\hline \multirow[t]{2}{*}{ Former lead arranger $_{D}$} & $-0.029 * * *$ & -0.026 & $* *$ & -0.029 & $* * *$ & -0.027 & $* *$ \\
\hline & -2.640 & -2.360 & & -2.680 & & -2.400 & \\
\hline \multirow[t]{2}{*}{ Spread level } & $0.004 * * *$ & 0.003 & $* * *$ & 0.004 & $* * *$ & 0.003 & $* * *$ \\
\hline & 27.310 & 25.530 & & 27.110 & & 25.400 & \\
\hline \multirow[t]{2}{*}{ Relative loan size } & -0.001 & 0.000 & & -0.001 & & 0.000 & \\
\hline & -0.750 & -0.300 & & -0.750 & & -0.370 & \\
\hline \multirow[t]{2}{*}{ Large $\operatorname{loan}_{\mathrm{D}}$} & & -0.176 & $* * *$ & & & -0.168 & $* * *$ \\
\hline & & -15.150 & & & & -14.530 & \\
\hline \multirow[t]{2}{*}{ Lead arranger market share } & -0.396 & -0.165 & & & & & \\
\hline & -1.440 & -0.590 & & & & & \\
\hline \multirow[t]{2}{*}{ Top lead arranger $_{\mathrm{D}}$} & & & & -0.083 & $* * *$ & -0.065 & $* * *$ \\
\hline & & & & -6.480 & & -4.980 & \\
\hline Year dummies & yes & yes & & yes & & yes & \\
\hline Industry dummies & yes & yes & & yes & & yes & \\
\hline Loan purpose dummies & yes & yes & & yes & & yes & \\
\hline Pseudo log-likelihood & $-8,049$ & $-7,885$ & & $-8,019$ & & $-7,866$ & \\
\hline Pseudo $\mathrm{R}^{2}$ & 0.245 & 0.260 & & 0.248 & & 0.262 & \\
\hline Number of observations & 16,598 & 16,598 & & 16,598 & & 16,598 & \\
\hline
\end{tabular}


Table V

Determinants of spread rounding

Panel B: Predicted probabilities of a loan being priced at a rounded spread above LIBOR

Predicted probabilities based on regression (4) in Panel A

\begin{tabular}{|c|c|c|c|}
\hline & From & To & Change \\
\hline Unrated borrower $_{\mathrm{D}}$ & $39.0 \%$ & $85.7 \%$ & $46.7 \%$ \\
\hline Borrower without ticker $_{D}$ & $69.3 \%$ & $73.3 \%$ & $4.0 \%$ \\
\hline Previous borrower & $70.9 \%$ & $70.3 \%$ & $-0.6 \%$ \\
\hline Former lead arranger $_{D}$ & $66.1 \%$ & $64.2 \%$ & $-2.0 \%$ \\
\hline Spread level & $52.3 \%$ & $84.3 \%$ & $32.0 \%$ \\
\hline Relative loan size & $70.7 \%$ & $70.6 \%$ & $-0.1 \%$ \\
\hline Large $\operatorname{loan}_{\mathrm{D}}$ & $71.5 \%$ & $57.2 \%$ & $-14.3 \%$ \\
\hline Lead arranger market share & $71.3 \%$ & $68.8 \%$ & $-2.5 \%$ \\
\hline Top lead arranger $_{D}$ & $71.6 \%$ & $69.6 \%$ & $-2.0 \%$ \\
\hline
\end{tabular}


Table VI

\section{Determinants of the degree of spread rounding}

This table shows results of ordered logit regressions. The ordered logit regression captures the ordinal nature of the dependent variable. In regression model (1), the dependent variable is split into 3 categories: non-rounded spreads, spreads rounded at multiples of 25 bp but not 50 bp, spreads rounded at multiples of $50 \mathrm{bp}$. In regression model (2), the dependent variable is split into 4 categories: non-rounded spreads, spreads rounded at multiples of $25 \mathrm{bp}$ but not $50 \mathrm{bp}$ or $100 \mathrm{bp}$, spreads rounded at multiples of $50 \mathrm{bp}$ but not $100 \mathrm{bp}$, spreads rounded at multiples of $100 \mathrm{bp}$. The marginal effect is reported in the top row and the z-statistic is reported in the bottom row. For dummy variables, the marginal effect of a change from 0 to 1 is reported. All marginal effects are calculated at the means. $* * * * *$ and $*$ indicate significance at the $1 \%, 5 \%$ and $10 \%$ level respectively. The regression model contains an intercept. Standard errors are heteroscedasticity robust and clustered at the borrower level. Subscript D indicates a dummy variable.

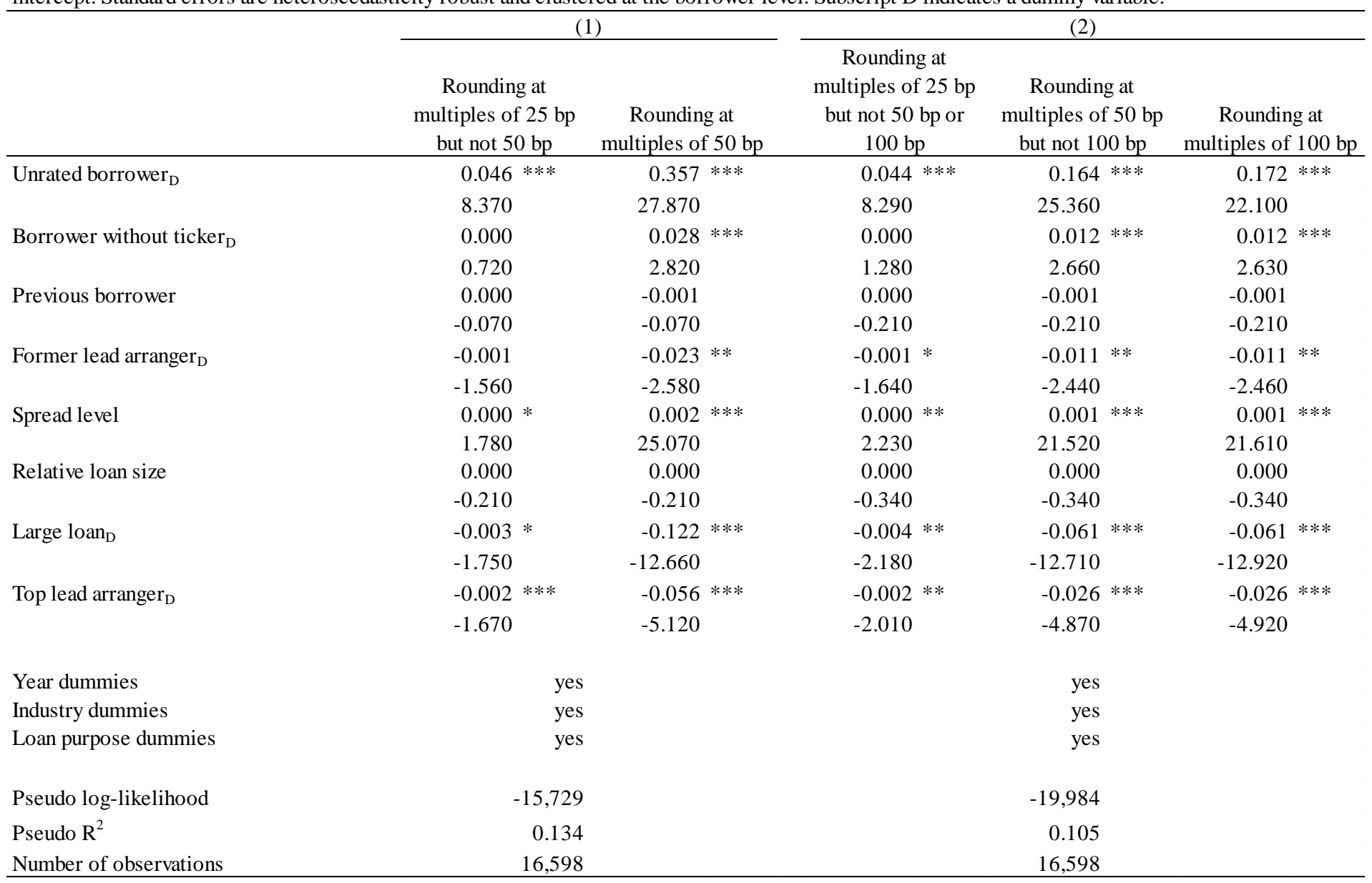


Table VII

\section{Robustness checks regarding loans with extreme spreads}

This table shows results of logit regressions based on reduced samples. The dependent variable is coded as 1 when the spread over LIBOR of the loan tranche is rounded at 25 or a mutliple thereof and 0 otherwise. The marginal effect is reported in the top row and the z-statistic is reported in the bottom row. For dummy variables, the marginal effect of a change from 0 to 1 is reported. All marginal effects are calculated at the means. ***, ** and $*$ indicate significance at the $1 \%, 5 \%$ and $10 \%$ level respectively. The regression model contains an intercept. Standard errors are heteroscedasticity robust and clustered at the borrower level. Subscript D indicates a dummy variable.

\begin{tabular}{|c|c|c|c|c|}
\hline \multirow[t]{3}{*}{ Dependent variable } & \multicolumn{4}{|c|}{ Rounded spread $_{D}$} \\
\hline & (1) & $(2)$ & $(3)$ & (4) \\
\hline & $\begin{array}{c}\text { Exclude top } 1 \% \\
\text { spreads }\end{array}$ & $\begin{array}{c}\text { Exclude top 5\% } \\
\text { spreads }\end{array}$ & $\begin{array}{l}\text { Exclude top and } \\
\text { bottom } 1 \% \\
\text { spreads }\end{array}$ & $\begin{array}{c}\text { Exclude top and } \\
\text { bottom 5\% } \\
\text { spreads }\end{array}$ \\
\hline \multirow[t]{2}{*}{ Unrated borrower $_{D}$} & $0.466 * * *$ & $0.472 * * *$ & $0.464 * * *$ & $0.440 * * *$ \\
\hline & 28.360 & 28.670 & 28.200 & 25.070 \\
\hline \multirow[t]{2}{*}{ Borrower without ticker $_{D}$} & $0.039 * * *$ & $0.039 * * *$ & $0.039 * * *$ & $0.034 * * *$ \\
\hline & 3.150 & 3.070 & 3.210 & 2.830 \\
\hline \multirow{2}{*}{ Previous borrower } & -0.011 & -0.012 & -0.012 & -0.014 \\
\hline & -1.000 & -1.010 & -1.030 & -1.270 \\
\hline \multirow[t]{2}{*}{ Former lead arranger ${ }_{D}$} & $-0.027 * *$ & $-0.028 * *$ & $-0.026 * *$ & $-0.025 * *$ \\
\hline & -2.370 & -2.370 & -2.360 & -2.250 \\
\hline \multirow[t]{2}{*}{ Spread level } & $0.003 * * *$ & $0.004 * * *$ & $0.003 * * *$ & $0.003 * * *$ \\
\hline & 25.090 & 25.870 & 25.090 & 24.240 \\
\hline \multirow[t]{2}{*}{ Relative loan size } & 0.000 & 0.000 & 0.000 & 0.000 \\
\hline & -0.360 & -0.370 & -0.380 & -0.530 \\
\hline \multirow[t]{2}{*}{ Large loan ${ }_{D}$} & $-0.172 * * *$ & $-0.173 * * *$ & $-0.168 * * *$ & $-0.146 * * *$ \\
\hline & -14.510 & -14.230 & -14.370 & -12.670 \\
\hline \multirow[t]{2}{*}{ Top lead arranger ${ }_{D}$} & $-0.066 * * *$ & $-0.066 * * *$ & $-0.064 * * *$ & $-0.059 * * *$ \\
\hline & -4.940 & -4.780 & -4.830 & -4.550 \\
\hline Year dummies & yes & yes & yes & yes \\
\hline Industry dummies & yes & yes & yes & yes \\
\hline Loan purpose dummies & yes & yes & yes & yes \\
\hline Pseudo log-likelihood & $-7,842$ & $-7,723$ & $-7,804$ & $-7,510$ \\
\hline Pseudo $\mathrm{R}^{2}$ & 0.258 & 0.255 & 0.253 & 0.216 \\
\hline Number of observations & 16,317 & 15,874 & 16,200 & 15,131 \\
\hline
\end{tabular}


Determinants of fraction of base rates with rounded spreads

This table shows results of tobit regressions. The dependent variable is the number of base rates with rounded spreads as a fraction of the total number of base rates. The coefficient is reported in the top row and the t-statistic is reported in the bottom row. $* * *, * *$ and $*$ indicate significance at the $1 \%$, $5 \%$ and $10 \%$ level respectively. Standard errors are heteroscedasticity robust and clustered at the borrower level. Subscript D indicates a dummy variable.

\begin{tabular}{|c|c|}
\hline Dependent variable & $\begin{array}{c}\text { Fraction of base rates with } \\
\text { rounded spread }\end{array}$ \\
\hline Intercept & $1.001 * * *$ \\
\hline Unrated borrower $_{D}$ & $\begin{array}{l}9.270 \\
0.629 * * *\end{array}$ \\
\hline Borrower without ticker $_{D}$ & $\begin{array}{r}21.770 \\
0.038 *\end{array}$ \\
\hline & 1.660 \\
\hline Previous borrower & $\begin{array}{l}0.005 \\
0.310\end{array}$ \\
\hline Former lead arranger ${ }_{D}$ & $\begin{array}{l}-0.046 * * \\
-2.430\end{array}$ \\
\hline Spread level & $\begin{array}{l}0.004 * * * \\
21.310\end{array}$ \\
\hline Relative loan size & $\begin{array}{l}-0.001 * \\
-1.760\end{array}$ \\
\hline Large loan ${ }_{D}$ & $-0.297 * * *$ \\
\hline Top lead arranger $_{D}$ & $\begin{array}{c}-14.050 \\
-0.078 \text { *** } \\
-3.400\end{array}$ \\
\hline Year dummies & yes \\
\hline Industry dummies & yes \\
\hline Loan purpose dummies & yes \\
\hline Pseudo log-likelihood & $-12,083$ \\
\hline Pseudo $R^{2}$ & 0.152 \\
\hline Number of observations & 16,598 \\
\hline
\end{tabular}


Table A-I

\section{Variable definitions}

\section{Rounded spread ${ }_{D}$}

Spread level

Unrated borrower

Borrower without ticker

Previous borrower

Former lead arranger

Relative loan size

Large Loan $_{D}$

Lead arranger market share

Top lead arranger

S\&P senior debt rating class $B_{D}$ S\&P senior debt rating class $C_{D}$ $S \& P$ senior debt rating class $D_{D}$

Borrower size

Tranche size

Loan maturity

Secured $_{D}$

Senior $_{\mathrm{D}}$

Covenants $_{\mathrm{D}}$

Term loan ${ }_{D}$

Multiple tranche $e_{D}$

Year dummies

Loan purpose dummies

Industry dummies
Dummy $=1$ if the loan tranche is priced at a spread of 25 basis points or a multiple thereof, 0 otherwise.

Spread over LIBOR in basis points from the "Base Rate Margin" field in LPC's Dealscan database.

Dummy $=1$ if the borrower has no S\&P senior debt rating, 0 otherwise.

Dummy $=1$ if the borrower has no ticker, 0 otherwise.

Number of loans rasied by a borrower in 3 years prior to loan signing.

Dummy $=1$ if the lead arranger has been a lead arranger to the same borrower in 3 years prior to loan signing, 0 otherwise.

Tranche amount divided by borrower sales.

Dummy $=1$ for loans that belong to the top- $33 \%$ of the sample in terms of loan size in the year of loan signing.

Lead arranger reputation measured by the market share of the lead arranger in the year prior to loan signing $(1=1 \%)$. Average market share in case of multiple lead arrangers, 0 otherwise.

Dummy $=1$ if at least of the lead arrangers is among the three lead arrangers with the highest market share in the year of loan signing, 0 otherwise.

Dummy $=1$ if the borrower has $\mathrm{S} \& \mathrm{P}$ senior debt rating in class $\mathrm{B}, 0$ otherwise.

Dummy $=1$ if the borrower has $\mathrm{S} \& \mathrm{P}$ senior debt rating in class $\mathrm{C}, 0$ otherwise.

Dummy $=1$ if the borrower has S\&P senior debt rating in class D, 0 otherwise.

Natural logarithm of the borrower's sales volume in millions of dollars at the time of loan signing.

Natural logarithm of the tranche amount in millions of dollar.

Natural logarithm of average maturity across all tranches belonging to the same deal, measured in years.

Dummy $=1$ for secured tranches, 0 otherwise.

Dummy $=1$ for senior loan tranches, 0 otherwise

Dummy $=1$ for tranches with covenants, 0 otherwise.

Dummy $=1$ if at least one tranche in the deal is a term loan, 0 otherwise.

Dummy $=1$ if deal consists of more than one tranche, 0 otherwise.

Dummies indicating in which year the loan was signed. Individual dummies for each year from 1988 to 2010 are created. The dummy for year 1988 is excluded as the benchmark year.

Dummies indicating the different reasons why borrowers raised funds based on Dealscan's "Primary Loan Purpose" field. Individual dummies for acquisition, corporate purpose, and debt repayment are created. The dummy for working capital is excluded as the benchmark loan purpose.

Dummies for the industry of the borrower based on Dealscan's "Major Industry Group" field. Individual dummies for financial services, general manufacturing, healthcare, oil and gas, retail \& supermarkets, and technology are created. The dummy for aerospace is excluded as the benchmark industry. 